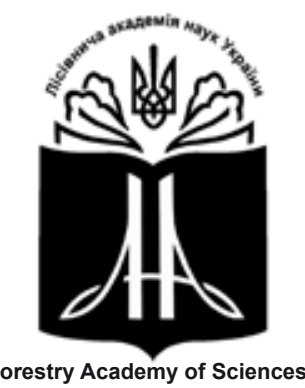

of Ukraine

Наукові праці Лісівничої академії наук України Proceedings of the Forestry Academy of Sciences of Ukraine

http://fasu.nltu.edu.ua

https://doi.org/10.15421/411820

Article received 2018.06.18

Article accepted 2018.10.25
ISSN 1991-606X print

ISSN 2616-5015 online

@ $₫$ Correspondence author

Vasyl Yukhnovskyi

yukhnov@ukr.net

General Rodimtsev str., 19, Kyiv, 03041, Ukraine

УДК 502-025.17:711.4

\title{
Типологія і класифікація як методи категоризації зеленого простору
}

\author{
В.Ю. Юхновський ${ }^{1}$ О.В. Зібцева²
}

Проаналізовано типології зеленого простору і класифікації парків у пострадянських (Україна, Білорусь), європейської (Великобританія), північноамериканських (США, Канада), азійських (Японія, Китай, Сінгапур, Малайзія) країнах та містах Австралії. Різні країни пропонують не однакові класифікації зеленого простору, щуо трунтуються на функиіональному призначенні території, фізичних характеристиках, розмірах, обсягах обслуговування населення тощзо. Охарактеризовано класифікацію парків, застосованої в Украйні, за місцем розташування відносно міських меж (міські парки і лісопарки) та за функціональною ознакою. Парки, залежно від характеру і призначення, поділяють на парки культури і відпочинку, районні, спортивні, дитячі, дендрологічні, історичні, національні, меморіальні, етнографічні парки-музеї, історичні, виставкові, зоологічні, парки аерофітотерапії тощьо. Відсутність ієрархічної класифікачії і відповідних стандартів призводить до поглинання зеленого простору міською забудовою.

Здійснено пошук иляхів удосконалення класифікації озеленених територій, використовуваної в Україні. Природні території та зелені насадження обмеженого користування (шкільні ділянки, спортивні майданчики житлових масивів) є найуразливішими територіями, які першочергово підпадають під забудову в украӥнських містах. Чітко визначена класифікація озеленених територій сприятиме їх збереженню в умовах посилення урбанізаиії. Рекомендовано стандартизувати українську класифікацію зелених насаджень у тому числі й за ієрархічними ознаками, щуо вплине не тільки на міську систему зелених насаджень, але й на ландшафтну організацію простору за межами міст.

Ключові слова: зелена інфраструктура; зелені насадження; парк; ландщафтна організащія простору; озеленення; рекреація; міські ліси.

Вступ. На відміну від звичного для пострадянського простору терміну «зелені насадження», у більшості країн загальноприйнятим $є$ поняття «міський зелений простір», а в останні десятиріччя - і «зелена інфраструктура». Міський зелений простір - це всі рослинні покриви у містах та навколо них, враховуючи міські ліси, пасовища, парки, сади, зелені дахи, міські ферми та вуличні дерева, які надають екосистемні послуги і відіграють важливу роль у пом'якшенні негативних наслідків урбанізації, сприяють соціальній єдності, а також надають численні психологічні переваги, важливі естетичні та відновлювальні можливості міським жителям (Yu et al., 2017). Парки, ігрові поля, кишенькові простори, двори, водойми, випадкові простори, вільні місця, домашні сади і вулиці є основними елементами зеленої інфраструктури, де відбувається взаємодія $з$ природою та людьми (Mansor, Said \& Mohamad, 2012).

Низка екологічних дисциплін пропонує різні назви міської системи зелених просторів, а саме: система садових зелених земель, міських зелених зе-

1 Юхновський Василь Юрійович - академік Лісівничої академії наук України, доктор сільськогосподарських наук, професор кафедри відтворення лісів та лісових меліорацій. Національний університет біоресурсів і природокористування України, вул. Генерала Родимцева, 19, м. Київ, 03041, Україна. Тел.: +38-067-720-32-16. Е-mail: yukhnov@ukr.net

2 Зібцева Ольга Василівна - кандидат сільськогосподарських наук, доцент кафедри ландшафтної архітектури та садово-паркового будівництва. Національний університет біоресурсів і природокористування України, вул. Генерала Родимцева, 19, м. Київ, 03041, Україна. Тел.: +38-050-835-77-74. E-mail: stplut2017@gmail.com 
мель, екологічних зелених земель, міський зелений простір, зелений відкритий простір. У цих поняттях вкладено садове, екологічне, просторове значення, які постійно розвиваються 3 удосконаленням теоpiї міста (Manlun, 2003). Водночас відсутність чітко визначеного терміна «зелений простір» під час планування міст сприяє зростанню площ забудови саме за рахунок зелених просторів (Hannikainen, 2012; Rakhshandehroo, 2014), що робить це питання надзвичайно актуальним.

Відкриті простори, зокрема зелені простори, в міських системах поділяють на три рівні: регіональний, урбональний (рівень міста) і локальний. Підтримка стійкості міст передбачає підтримку зелених просторів, зв'язку між ними і доступу для громадян на кожному рівні (Dhanapal \& Chaudhry, 2012). Для цього потрібні знання взаємозв'язків між соціально-демографічними характеристиками користувачів, особливостями зелених просторів та типами їх використання (Rey, Barrigon, Montes \& Atanasio, 2018).

Зелені простори групують у різні класи відповідно до певних класифікаційних стандартів, зокрема за формою. Однак найпрактичнішим і найефективнішим методом класифікації є класифікація, яка грунтується на функціях зелених насаджень (Manlun, 2003). Наразі у світі немає єдиного методу класифікації системи зелених просторів. Різні країни пропонують власні класифікації, основані як на функціях, так і на розмірі та фізичних характеристиках. Багато типологій розроблено впродовж останнього десятиліття (Meredith \& Salas Olmedo, 2011), деякі 3 них можуть використовуватися для міжнародних порівняльних досліджень.

У міському плануванні, зазвичай, існує конфлікт між міським розвитком та підтримкою навколишнього середовища. Схоже, що зелені простори навмисно залишалися невизначеними, щоб забезпечити їх подальшу забудову. Khalil (2014) вважає, що класифікація є першим кроком до організації, оцінювання та управління міськими зеленими просторами і що є потенціал для створення класифікації зелених просторів, яка буде використовуватися у генеральному плануванні.

Відсутність чітко визначеної, закріпленої на законодавчому рівні, термінології щодо зеленого простору і зелених насаджень робить їх уразливими у процесі містобудівного планування розвитку міст, тому наведене дослідження є надзвичайно актуальним.

Об'єкти і методика досліджень. Об ' $\epsilon$ 'к дослідження - типологія зеленого простору в різних країнах світу. Предмет дослідження - аналіз типології зеленого простору і класифікації міських парків різних країн світу методом категоризації.

Мета роботи - порівняти типології зелених просторів і класифікації міських парків, які використовують у різних країнах світу та в Україні, для пошуку шляхів удосконалення останньої.

Дослідження проведено на основі аналізу літературних джерел щодо систематики зелених про- сторів (Byrne \& Sipe, 2010, Ibes, 2015, Khalil, 2014; Liu, 2008, Nochian, Tahir, Maulan \& Rakhshanderoo, 2015 та ін.), нормативних документів (New park development, 2017, Parks and amenity open space strategy, 2013, Scottish nature heritage, 2005 та ін.) 3 використанням системного підходу та порівняльного аналізу. Проаналізовано типології зеленого простору і класифікації парків, які використовують у пострадянських, європейських (Великобританія), північноамериканських (США, Канада), азійських (Японія, Китай, Сінгапур, Малайзія) країнах та в містах Австралії.

Аналіз проблеми та обговорення. Існує два методи категоризації відкритого простору: типологія і класифікація (Nochian et al., 2015). Якщо типологія стосується типів відкритого простору без урахування їх внутрішніх характеристик, то класифікацію використовують тоді, коли категоризація містить внутрішні характеристики простору. Своєю чергою класифікаційний метод розподілу відкритого простору містить три підходи: ієрархія охоплення, або обслуговування (хто буде використовувати відкритий простір), функції (роль відкритого простору) i ландшафтні характеристики (структура простору). Обсяг обслуговування зумовлюється географічною територією, розміром, рівнем використання, віддаленістю. Кожен відкритий простір за функціональною класифікацією відображає своє основне використання, яке разом з очікуваним видом діяльності визначає три основні види відкритих просторів: рекреаційні, спортивні і природні. Ландшафтну характеристику використовують для того, щоб визначити оптимізований ландшафт, або тип рослинності. Кожне місто або країна має свої власні критерії класифікації відкритих просторів. Класифікації допомагають місцевій владі визначати основні стандарти обслуговування і необхідні об'єкти за функціональними та природоохоронними характеристиками. Є спроби об'єднання всіх трьох підходів «ієрархія обслуговування», «функція» та «ландшафтна структура» у вигляді комплексної класифікації зелених просторів.

Ефективна типологія міської зеленої інфраструктури має визначати сучасний стан розвитку міграційних потоків міст та напрями щодо впровадження зеленої інфраструктури як компонента міської інфраструктури (Young, Zanders, \& Fassman-Beck, 2014). Типологію, як наукову дисципліну та метод дослідження, широко використовують у різних галузях як надійний інструмент систематизації наявних і ще не достатніх знань. Водночас типології, які не мають специфічного, місцевого розуміння елементів, мають обмежену цінність.

Способи класифікації міського відкритого та зеленого простору, як зазначено вище, різняться розміром, функціональним призначенням, місцем розташування тощо (Bilgili \& Gokyer, 2012). Важливо, щоб класифікація зеленого простору не обмежувала міських планувальників жорсткими категоріями (Byrne \& Sipe, 2010). Stanley, Stark, Johnston \& Smith (2012). Виділяють сім категорій міського 
відкритого простору: площі виробництва продуктів харчування, сади і парки, рекреаційний простір, майданчики, вулиці, транспортні об'єкти та випадковий простір. Nochian et al. (2015) пропонують класифікацію відкритого простору за категоріями використання $з$ позицій стабільного розвитку. За оцінкою авторів, функціональна класифікація $є$ зрозумілішою.

Зазвичай, у визначенні відкритого зеленого простору фігурують форма, цілі, або функції (Manlun, 2003). Так, у Британії - це житлові землі, де землі під архітектурою становлять менше 1/20 загальної площі (не враховуючи пустирів): внутрішні двори, рекреаційні землі. Для США характерні декілька варіантів: землі з природним середовищем (рекреаційні та землі для регульованої міської забудови); землі не архітектурного використання (повітряного, грунтового, водного). У Японії - це також землі не архітектурного використання: парки, сквери, гімназії, зоо- і ботанічні сади; а також ігрові землі, кладовища, ферми, лісові землі. Крім того, визначено дев'ять просторових типів неформальних зелених просторів (Rupprecht \& Furuya, 2017).

Структурування можуть включати фізичний вигляд, просторову структуру та складність, соціальну функцію, власність та доступ, кількість та якість наданих екосистемних послуг, роль у збереженні біорізноманіття, інтенсивність впливу людини, відповідне призначення у плануванні та просторову стратегію. За результатами Green surge project (2013-2017), у Німеччині ідентифіковано 44 елементи відкритої зеленої системи, які згруповано у вісім категорій (Cvejić et al., 2015).

Типологія зелених просторів Великобританії $\epsilon$ лише керівництвом, яке на практиці інтерпретується в локальні типології залежно від місця і потреби (Kafafy, 2010). Так, у Лондоні класифікація системи відкритих просторів грунтується лише на ієрархії обслуговування (охоплення): парки поділяють на регіональні, столичні, районні, місцеві, кишенькові, за винятком «лінійного відкритого простору», який може бути об'єктом функціональної класифікації (Nochian et al., 2015). Місто Саутгемптон має чітку функціональну класифікацію (Kafafy, 2010), побудовану на вимірі дистанції до п'яти категорій зеленого простору: міський, районний, місцевий парки, приємний зелений простір та інші зелені простори. Містечко Сендвіч (Східний Кент) використовує такі типологічні категорії: природний та напівприродний відкритий простір, сади та парки, зручний відкритий простір, зелений коридор, сільська зелень, неформальне місце, неформально відтворюваний простір та закриті церковні вежі, спортивні споруди на відкритому повітрі, дитячий ігровий простір (Parks and amenity open space strategy, 2013).

Шотландська природна спадщина (Scottish nature heritage, 2005) виділяє громадські сади та парки, приватні сади або майданчики, приємний зелений простір; ігровий простір для дітей та підлітків; спортивні майданчики; зелені коридори; природні (напівприродні) зелені простори, інші функ- ціональні зелені простори (наділи, церковні вежі та цвинтарі). Установа «Зелений простір Шотландії» розвиває таксономію зелених просторів залежно від їх призначення та використання: простори для дихання, здоров'я, життя, зустрічей, для ігор, роботи, проведення свят (Kafafy, 2010).

Основними типами відкритих просторів у Непалі є парк, ігровий майданчик, релігійна ділянка, водна поверхня, печера, точка естетичного огляду, річкова смуга та грунтові ділянки (Pokharel \& Khanal, 2018). Відкриті простори різняться за формою, розміром, власником та функціями. Своєю чергою парки поділяють на офіційні сади, меморіали, міні-парки, зелені парки, інституційні, тематичні (спеціалізовані).

Різні країни адаптували метод класифікації, що грунтується на функціях до класифікації їх національних систем зелених просторів. Порівняльний аналіз класифікацій зеленого простору далекосхідних країн Китаю і Японії показав наступне (табл.).

За даними Китайського геологічного університету, у Китаї виділяють такі типи міських зелених просторів: публічні, житлові, захисні, виробничі, дорожні та простори установ (Liu, 2008). Класифікація системи міських зелених просторів у Китаї містить ієрархічні перший і другий класи (див. табл.). У ній парки поділено на муніципальні поліфункціональні, районні, житлові, 3оо- і ботанічні сади, дитячі парки і т.ін.

Класифікація міського зеленого простору в Китаї відповідно до національного стандарту «Стандарти класифікації міського зеленого простору» (Liu, 2008) також базується на їх функціях, але водночас містить більш чітко виражені ієрархічні ознаки в категорії парків, де виділяють зелений простір публічного парку, який своєю чергою містить 5 субкатегорій: поліфункціональний, суспільний, спеціалізований парки, бульвар або набережна, придорожній зелений простір. Субкатегорію комплексний (поліфункціональний) парк поділяють на підкатегорії: міський публічний парк, регіональний публічний; суспільний (житлового району, кварталу); спеціалізований (субкатегорії: дитячий парк, зоопарк, ботанічний, історичний, пейзажний, розважальний та ін.); бульвар, або набережна. Також виділяють виробничі зелені простори (різноманітні розсадники); захисні зелені території (санітарні, розподільчі, безпечні - аналогічно нашим санітарним захисним зонам); закріплені зелені простори другорядні зелені території (аналогічно нашим зеленим насадженням обмеженого користування, за винятком того, що тут є землі доріг) та інші зелені простори (території з прямим впливом на якість міського навколишнього середовища, відпочинок мешканців, вигляд міста і захист біорізноманіття).

В Японії також існує декілька класифікацій зеленого простору. Просторова класифікація (Manlun, 2003 ) містить чотири категорії: парки (повсякденного, районного, спеціального, регіонального використання, для спеціальних церемоній); сади пам'яті; дорожній простір; інші зелені просто- 
ри (сад маєтку, для гольфу, промисловий зелений простір). Класифікація всебічного зеленого планування Японії (Manlun, 2003) об’єднує дві категоpiï: публічні зелені простори (парки і зелені землі, сквери та ігрові майданчики, сади пам'яті, інші подібні зелені простори) та інші зелені простори (у т.ч. водні поверхні, смуги вздовж доріг, ферми, ліси, церковні сади, публічні зелені простори, сади маєтків, шкіл, сільськогосподарські дослідні поля площею понад $1000 \mathrm{~m}^{2}$ ).
XIX ст., яке називають епохою міста, ознаменувало прихід віку міського парку як лімітованого цілісного простору (Jones, 2018). Міський парк, як важлива частина міської зеленої просторової системи, наразі є основним місцем відпочинку мешканців, виконує різні екологічні функції і водночас $\epsilon$ втіленням соціально-економічного розвитку та духовної цивілізації міста ( $\mathrm{Zi}, 2011)$. Класифікують міські парки відповідно до їх фізичних, рослинних покривів і функцій.

Таблиияя

Класифікація системи міських зелених просторів у Китаї та Японії за Manlun (2003) i Liu (2008)

\begin{tabular}{|c|c|c|}
\hline \multicolumn{3}{|c|}{ Класи зелених просторів } \\
\hline Перший & Другий & Третій \\
\hline \multicolumn{3}{|c|}{ Зелені простори Китаю } \\
\hline Парк & $\begin{array}{l}\text { Муніципальний поліфункціональний парк, районний, } \\
\text { житловий, ботанічний сад, зоопарк, дитячий парк і т. ін. }\end{array}$ & - \\
\hline $\begin{array}{l}\text { Вуличні зелені } \\
\text { простори }\end{array}$ & $\begin{array}{c}\text { Малі декоративні сади, бульвари, садові смуги, } \\
\text { зелені простори майданів }\end{array}$ & - \\
\hline $\begin{array}{l}\text { Житлові зелені } \\
\text { простори }\end{array}$ & $\begin{array}{c}\text { Зелені простори в житловому районі, житлових } \\
\text { кварталах, вуличних територіях }\end{array}$ & - \\
\hline $\begin{array}{l}\text { Зелені простори } \\
\text { при офісах }\end{array}$ & $\begin{array}{l}\text { Зелені простори фабрик, шкіл, лікарень, готелів, } \\
\text { складів, публічних муніципальних територій тощо }\end{array}$ & - \\
\hline $\begin{array}{l}\text { Зелені простори } \\
\text { доріг }\end{array}$ & Дерева вздовж доріг, смуги відведення при дорогах & - \\
\hline $\begin{array}{l}\text { Захисні зелені } \\
\text { простори }\end{array}$ & $\begin{array}{l}\text { Рекреаційні ліси, лісонасадження промисловості, ліси } \\
\text { вітрозахисні, водоохоронні, грунтозахисні, болота }\end{array}$ & - \\
\hline $\begin{array}{l}\text { Виробничі зелені } \\
\text { простори }\end{array}$ & Розсадники, квітникарські сади, трав'яні сади та ін. & - \\
\hline $\begin{array}{l}\text { Ландшафтні зелені } \\
\text { простори }\end{array}$ & $\begin{array}{c}\text { Ландшафтні ліси, лісові парцели та інші } \\
\text { автономні лісові ділянки }\end{array}$ & - \\
\hline $\begin{array}{l}\text { Приміські зелені } \\
\text { простори }\end{array}$ & $\begin{array}{c}\text { Ландшафтні площі, лісові сади, природоохоронні ліси, } \\
\text { ліси для захисту водопостачання, лісова мережа ферм, } \\
\text { плодові сади, інші лісові землі }\end{array}$ & - \\
\hline
\end{tabular}

Зелені простори Японії

Публічний зелений простір

стежки, ігрові майданчики, велодоріж,

Сквери

Парки пам'яті

Річка, озеро, потік

Публічний зелений простір
Природний зелений простір

\begin{tabular}{cc} 
& Гірські ліси, пагорби, ферми \\
\hline Відкритий зелений простір & Церковні сади, пам’ятні сади \\
Садові ділянки доступні для загального \\
використання \\
Інші садові ділянки
\end{tabular}

Загальні житлові садові ділянки

Загальні рекреаційні місця

Зелений простір загального (сумісного) користування

Приватний зелений простір
Місця рекреації підприємств

Шкільні та інші садові ділянки

Індивідуальні садові ділянки, Дослідні ділянки розсадників

Постачання води, дренажу та ін. 
За даними Manlun (2003), класифікація парків у США містить категорії: дитячий парк, малий сад, сусідній парк, районний, великий міський, регіональний, спеціальні обладнані об'єкти (у т. ч. авеню, морське узбережжя, історичні сади, заплави, малі парки, газони, лісові землі і т.ін.). Byrne \& Sipe (2010) виділяють такі типи парків: кишеньковий (ігровий майданчик), сусідства, громадський, районний, регіональний, природний (національний). У Феніксі, Арізона, виділено п'ять типів парків: приміські, розважальні, зелені міні-парки (сквери), сусідства та міські, а також місцеві резервуари (природні залишки) (Ibes, 2015). У штаті Мічиган (США) чітко не визначено, які фактори використовують для класифікації відкритого простору. Більшість категорій обгрунтовується за функцію, деякі елементи представлені ієрархією (Nochian et al., 2015). Класифікація містить: міні-парк, районний, шкільний, суспільний, великий міський, природні території, зелені дороги, спортивні комплекси, території спеціального використання, приватні парки відпочинку. У місті Кун Рапідс (Міннєсота) діє уніфікована класифікація системи відкритих просторів, яка не є чіткою класифікацією: в ній змішані як ієрархії обслуговування, так і функції, проте вплив функціональної класифікації очевидніший. Представлені: міні і парк сусідства, суспільний парк, молодіжний і суспільний атлетичні комплекси, суспільний заповідник, захисний відкритий простір, спеціалізований і регіональний парки, шкільна ділянка. За оцінкою авторів, функціональна класифікація $є$ більш зрозумілою.

Класифікація парків міста Оттава, як і в містах США, встановлює типи парків та окреслює стандарти щодо їх розміру, розміщення, радіуса зони обслуговування, конфігурації та зручностей, що дає їй змогу бути еталонним інструментом розроблення нових парків і найкращим чином задовольняти потреби громад. Вона містить шість типів міських парків: окружний, районний, громадський, парк сусідства, паркет (плаза) та лісопарк.

У класифікації систем відкритих просторів Австралії (Nochian et al., 2015) використовують всі три підходи: функціональний, ієрархічний і ландшафтну класифікацію. У Стратегії відкритих місць і відпочинку міста Маріон використано класифікацію рівнів (ієрархії та рівень охоплення: локальний, районний, окружний, регіональний та рівень державних земель). Функціональна класифікація містить категорії: території для відпочинку; фізичної активності, зв'язку; туризму; візуального комфорту; некласифіковані території. Ландшафтна класифікація (за ознаками території) містить такі категорії: регулярні, ландшафтні; дернина, газон; водна поверхня, природна територія, заболочена земля, дренажна, циклонна вода, буфер, тверда поверхня, прибережна, некласифікована. На відміну від класифікації решти австралійських міст, місто Мельбурн володіє класифікацією простору на основі ієрархії та характеру, хоча в ній є також і ландшафтні риси (Nochian et al., 2015). Ієрархія відкритого простору містить рівні столиці, держави, регіону, муніципалітету, району, місцевий, малої локації, зв'язку малої локації. За функціональними ознаками виділяють: ботанічний, цивільний простір, для заходів, офіційний, спадковий, неформального використання, лінійний, з'єднувальний простір, збереження природи, ігровий, смуга відчуження залізниці, судноплавна, частина каналу, рекреації, занять спортом для обмеженого кола, місця для сидіння, огляду, для обслуговування, резервування важливих доріг, спортивні, майдани, нерозвинуті, міські площі (торгові центри), водойми, водні шляхи.

У класифікації Сінгапура (Nochian et al., 2015), як і в США, також немає чіткої класифікації системи відкритих просторів, але переважає функціональна ознака, використовують класи: відкритий простір, парк, пляжна зона, зона спорту і відпочинку. Кожен 3 цих класів має свій спектр просторів. Так, відкриті простори поділяють на лісові, болота, природні відкриті, публічні променади; парки поділяють на національні, регіональні, громадські (районні), паркипоєднувачі, зоологічні і ботанічні сади.

У Малайзії класифікацію відкритих міських просторів здійснюють на трьох рівнях: національному, штату і міста (Nochian, et al., 2015). Класифікація відкритого простору для рекреаційних цілей на національному рівні базується переважно на охопленні (обслуговуванні) та ієрархії. Втім, поля для ігор, майданчики для дітей та дахи-сади можуть розглядатися як функціональні ознаки. Окрім національної класифікації, є місцеві класифікації системи відкритих просторів. У найгустонаселенішому штаті Селангор з високим рівнем життя, основною системою класифікації $є$ ієрархія охоплення, за винятком майданчика та ігрового поля. Класифікація системи відкритих просторів у КуалаЛумпур заснована на ієрархії обслуговування (за винятком «спорткомплексів», які категоризуються як «функція»). Хоча у Малайзії діє три рівні класифікації відкритого простору, переважно керуються ієрархією обслуговування (Nochian et al., 2015). 3 огляду на класифікаційні схеми, або типології зеленого простору, що використовують у різних країнах, було запропоновано розширену типологію для міського зеленого простору Куала-Лумпур, адаптовану до малайзійських умов (Yusof \& Johari, 2013), а також всеохопну (комплексну) класифікацію відкритого міського простору Малайзії (Nochian et al., 2015), яка поєднує всі три класифікаційні методи.

На пострадянському просторі класифікацію озеленених територій розглядають як спосіб систематизації озеленених територій залежно від розташування і функціонального призначення, а також площі. Класифікаційні схеми озеленених територій у багатьох пострадянських країнах, зазвичай, подібні. Наведемо класифікаційну схему, яку використовують у Білорусі, як більш чітко і однозначно прописану. Відповідно до «Правил проведення озеленення населених пунктів» Республіки Білорусь, озеленені території розподіляють на групи за місцем розташування (міські і приміські), переважа- 
ючим типом використання і функціональним призначенням (озеленені території загального користування, обмеженого користування і спеціального призначення, інші озеленені території). Озеленені території загального користування, призначені для організації різних видів відпочинку населення, містять: парки, сквери, сади, бульвари, лісопарки, гідропарки, лугопарки, ландшафтні парки, зони короткочасної рекреації біля води, міські ліси, озеленені ділянки громадських центрів загальноміського i районного значення (простежується втручання ієрархії. Парки поділяють на багатофункціональні, прогулянкові, природно-історичні, спеціалізовані, виставкові, дитячі, меморіальні, атракціонів, спортивні, тематичні. Природні парки поділяють на гідропарки, лісопарки, лугопарки, ландшафтні парки (за ландшафтною ознакою).

В Україні визначення і типологію «відкритого простору» не практикують (Yukhnovskyi \& Zibtseva, 2018). Українська система озеленення i класифікаційна структура побудована не на понятті території, відкритого або зеленого простору, а на понятті зелених насаджень. Згідно з Правилами утримання зелених насаджень у населених пунктах України (2006) зелені насадження - рослинність природного і штучного походження на визначеній території населеного пункту, зелені насадження загального користування - це зелені насадження на території загальноміських і районних парків, спеціалізованих парків, парків культури та відпочинку; на територіях зоопарків та ботанічних садів, міських садів і садів житлових районів, міжквартальних або при групі житлових будинків; скверів, бульварів, насадження на схилах, набережних, лісопарків, лугопарків, гідропарків та інших, які мають вільний доступ для відпочинку. Зелені насадження обмеженого користування - насадження на територіях громадських і житлових будинків, шкіл, дитячих установ, вищих та середніх спеціальних навчальних закладів, профтехучилищ, закладів охорони здоров'я, промислових підприємств і складських зон, санаторіїв, культурно-освітніх i спортивно-оздоровчих установ та інші. Зелені насадження спеціального призначення - насадження транспортних магістралей i вулиць; на ділянках санітарно-захисних зон довкола промислових підприємств; виставок, кладовищ і крематоріїв, ліній електропередач високої напруги; лісомеліоративні, водоохоронні, вітрозахисні, протиерозійні, насадження розсадників, квітникарських господарств, пришляхові насадження в межах населених пунктів. Такий історично сформований підхід спричиняє складності у порівняльні дослідження із європейськими та іншими містами i, що значно небезпечніше, в умовах прискореної урбанізації робить міські зелені насадження (як і у випадку з лісами у лісовому господарстві) відірваними від земель, на яких вони зростають, внаслідок чого вони стають уразливими і незахищеними.

Наразі в Україні актуальним є формування законодавчої бази щодо ефективної охорони зелених насаджень у містах, але вільне трактування проблеми правознавцями - не фахівцями галузі виявляється надзвичайно шкідливим. Tolkachenko (2009) наводить класифікацію зелених насаджень міста за функціональним призначенням, яка взагалі не збігається із загальноприйнятою, викладеною у професійній державній нормативній літературі й включає захисну рослинність, озеленювальні насадження, декоративну рослинність, плодову рослинність. Натомість прийнятий в Україні розподіл зелених насаджень за функціональною ознакою він трактує як не остаточний розподіл за «правовим режимом озелененого об'єкта благоустрою», який на його думку, може бути розширений залежно від критерію, взятого за основу класифікації.

На думку Sytnik (2014), наявна термінологічна різноманітність детермінує необхідність з'ясування сутності кожної із закріплених у законодавстві юридичних конструкцій та визначення того, який термін найбільш точно та повно характеризує землі, на яких розташовані зелені насадження у населених пунктах. Автор вважає, що визначення озеленених територій дещо конкурує 3 поняттям зелених зон. Насправді ж, схоже, що автор просто не знайомий із класифікацією зелених насаджень за територіальною ознакою: розподілом на міські і заміські, які разом утворюють комплексну зелену зону міста. Хоча, до викладення розділу ДБН 360-92 Містобудування. Планування і забудова міських і сільських поселень: «Ландшафтно-рекреаційна територія» 3 розподілом на озеленені території міста, зону відпочинку і курортну зону є багато питань). Зазначає, що де-факто, зелені зони міст на сьогодні існують, проте не мають належної законодавчої основи і не належать винятково до сфери регулювання ЗК України. На їі думку, у застосовуванні терміна «землі зелених насаджень міст та інших населених пунктів», як і у випадку із зеленими зонами, законодавець проводить певне термінологічне розмежування між правовим режимом земельних ділянок та правовим режимом розташованих на них зелених насаджень. На цій підставі автор вважає за необхідне проведення дослідження співвідношення земельних ділянок зелених зон та земельних ділянок зелених насаджень, що важко зрозуміти фахівцям. Втім ми цілком згодні з висновком автора про те, що наявна в законодавстві термінологія потребує суттєвого упорядкування для усунення принаймні термінологічних суперечностей. Дивує ствердження автора про те, що порушене питання детермінує необхідність 3'ясування співвідношення самої земельної ділянки та рослинності (зелених насаджень), що на ній розташована (хоча насправді наразі в Україні існує єдиний визначений термін - зелені насадження, яким позначаються всі класифіковані територіі). На нашу думку, логічна заміна поняття «зелені насадження» на прийняте у світі «зелений простір» усунуло б багато юридичних невизначеностей і взагалі сприяло б їх збереженню. Звичне для нас інтерпретування садово-паркових об'єктів, таких як парки, сквери зеленими насадженнями (а не територіями) 
iз вказівками мінімального рівня озеленення (наприклад, не менше 65 \%) виглядає алогічно.

Загалом класифікації парків, зазвичай, базуються на розмірах, функції, розташуванні та видах споруд в ньому, а іноді й ступені природності. Парки можуть бути міські, природні, кишенькові, районні, громадські, парки околиць, спортивні поля, міські ліси тощо. Є й інші способи класифікації парків, наприклад за такими факторами, як діяльність в їх межах, рівень відповідального управління, історія розвитку, стан, типи відвідувачів, рівень озеленення та облаштування, філософія розвитку. Поєднання цих різних факторів може призвести до різного роду комбінацій і перестановок, що робить уніфікований метод класифікації парків практично неможливим і досить безглуздим (Byrne \& Sipe, 2010).

Так, відповідно до PPG 17, місто Саутгемптон (2005) розробило місцеві стандарти, серед яких категоризація зелених просторів за багатофункціональним використанням. Виділено десять категорій відкритого простору, проте в стратегії пропонують використовувати лише п’ять. Спрощена ієрархія дає змогу встановити стандарти розміру й охоплення різних типів зеленого простору і надати планувальникам можливість удосконалювати простір для рівномірного забезпечення кожним типом по всьому місту.

Натомість в Україні, як і в наведеній вище класифікації озеленених територій Білорусі, використовують просту і досить зручну класифікацію парків за місцем розташування відносно міських меж: міські і заміські (зазвичай, лісопарки) та за функціональною ознакою. Наразі парки, залежно від характеру і призначення, поділяють на парки культури і відпочинку, районні, спортивні, дитячі, дендрологічні, історичні, національні, меморіальні, етнографічні парки-музеї, історичні, виставкові, зоологічні, аерофітотерапії тощо. Відсутність ієрархічної класифікації і відповідних жорстких стандартів призводить до нестримного наступу міської забудови на зелені території і порушення соціальної рівності щодо доступу до зелених насаджень, насамперед парків. Так, серед малих міст Київщини мають парки не більше третини міст. Крім того, традиційним стало недотримання стандартів мінімальних розмірів паркового середовища, яке й так має чітку тенденцію до зниження: на практиці парками називають озеленені території менше 2 га, які насправді за діючою класифікацією є скверами. Відсутність виділення чіткої категорії «шкільна ділянка» і чітких стандартів щодо іiі розмірів (як це зроблено, наприклад, у Сполучених Штатах), робить незахищеними від захоплення і забудови шкільні території і завдає непоправної шкоди когнітивному розвитку і благополуччю дітей. Відсутність чітко прописаного визначення і стандартів щодо залишків природних територій, незрівнянна екологічна цінність яких в межах міст не піддається сумніву за кордоном, робить їх найуразливішими територіями, що першочергово підпадають під забудову. Чіткі визначення, типологія і комплексна класифікація зеле- них просторів (зелених насаджень) та їх чітке нормування здатні впливати на уподобання, культуру i поведінку людей (що надзвичайно актуально для країни, що розвивається), а також на великомасштабне ландшафтне планування території поза межами міст.

Висновки і перспективи. Основними методами категоризації відкритого зеленого простору є типологія, яка стосується типів відкритого простору без урахування їх внутрішніх характеристик, і класифікація, яка враховує внутрішні кількісні та якісні показники простору.

Дієва типологія відкритого простору визначає сучасний стан та напрями розвитку і грунтується на специфічних місцевих елементах. Кожна країна і навіть місто мають власні класифікації зеленого простору, які допомагають місцевій владі визначати основні стандарти обслуговування. У низці країн (наприклад, у Великобританіiі), типологія зеленого простору є лише керівництвом, яке на практиці інтерпретується в локальні типології. Найпоширенішою у світі є адаптована до національних систем зеленого простору класифікація за функціональною ознакою, якої виявляється недостатньо. Використання ієрархічної класифікації (на національному, регіональному і міському рівнях) у таких країнах, як Малайзія, Австралія, частково - США, Канада та ін. робить можливим ландшафтне планування у національному масштабі з реалізацією основного принципу озеленення - рівномірності та стандартної доступності зеленого простору для всіх верств населення. Ієрархічна класифікація парків (наприклад, в Оттаві) і чіткі стандарти щодо їх розміру, розміщення, радіуса зони обслуговування робить пі еталонним інструментом розроблення нових рекреаційних просторів і зразком для наслідування. Далекосхідні країни використовують дворівневу (Китай) і трирівневу (Японія) класифікації зеленого простору з відповідними ступенями: місця загального користування, відкриті зелені простори, парки і ландшафтні об'єкти.

Існує нагальна потреба надання чіткого визначення та розроблення нормативів щодо зелених просторів відповідно до сучасних потреб суспільства, удосконалення наявної національної класифікації зелених насаджень. Потрібно чітко прописати (стандартизувати) і тим самим захистити території зелених насаджень обмеженого користування (озеленені території шкільних ділянок, спортивних майданчиків житлових масивів), залишки природних територій. Вважаємо за доцільне стандартизувати класифікацію зелених просторів за ієрархічними ознаками, що вплине не лише на міську систему зелених насаджень, але й на ландшафтну організацію простору за межами міст.

\section{Бібліографічні посилання}

Bilgili, B. C., \& Gokyer, E. (2012). Urbaun green space system planning. Landscape planning, 107-123. Dr. Murat Ozyavuz (Ed.). https://doi.org/ 10.5772/45877. 
Available from: http://www.intechopen.com/books/ landscape-planning/urban-green-space-systemplanning

Byrne, J., \& Sipe, N. (2010). Green and open space planning for urban consolidation - A review of the literature and best practice. Urban Research Program, Griffith University Brisbane, QLD 4111. Available from: http://hdl.handle.net/10072/34502

Cvejić, R., Eler, K., Pintar, M., Železnikar, Š., Haase, D., Kabisch, N., \& Strohbach, M. (2015). A typology of urban green spaces, ecosystem services provisioning services and demands. (May, 13, 2015). Report, D3.1, UBER, Germany, 10. Retrieved at: http://greensurge.eu/working-packages/wp3/files/ D3.1_Typology_of_urban_green_spaces_1.pdf

Dhanapal, G., \& Chaudhry, P. (2012). Open spaces for urban sustainability. Available from: http:// sustainabilityoutlook.in/content/open-spaces-urbansustainability

Hannikainen, M. (2012). Classification of green spaces in Helsinki and Vantaa. Classification of green spaces. Posted on October 22, 2012 by nlipsane

Ibes, D. C. (2015). A multi-dimensional classification and equity analysis of an urban park system: A novel methodology and case study application. Landscape and urban planning, 137, 122-137. https://doi. org/10.1016/j.landurbplan.2014.12.014

Jones, K. R. (2018). The Lungs of the City: Green Space, Public Health and Bodily Metaphor in the Landscape of Urban Park History. Environment and history, 24 (1), 39-58. https://doi.org/10.3197/09673 4018X15137949591837

Kafafy, N. A.-A. (2010). The dynamics of urban green space in an arid city; the case of Cairo- Egypt. A thesis submitted in fulfillment of the requirements of Cardiff University for the degree of Doctor in Philosophy. Published by ProQuest LLC 2013.

Khalil, R. (2014). Quantitative evaluation of distribution and accessibility of urban green spaces (Case study: City of Jeddah). International Journal of Geomatics and Geosciences, 4 (3), 526-535.

Liu, L. (2008). Status and prospects for urban green structure planning in China: Weihai city as a case study. Forest \& Landscape, University of Copenhagen.

Manlun, Y. (2003). Suitability analysis of urban green space system based on GIS. Enschede, Netherlands. Retrieved at: https://pdfs.semanticscholar.org/6307/5 8415ae57f5929bf5ddae76df33b1dd223d3.pdf

Mansor, M., Said, I., Mohamad, I. (2012). Experiential Contacts with Green Infrastructure's Diversity and Well-being of Urban Community. Procedia, Social and Behavioral Sciences, 49, 257-267. https://doi: 10.1016/j.sbspro.2012.07.024.

Meredith, D., \& Salas Olmedo, M. (2011). Understanding the potential role of spatial typologies in responding to the RURAGRI. Teagasc, Rural Economy Development Programme, Ashtown, Dublin 15. Ireland. Available from: RURAGRI WP4_Spatial_Typologies.pdf
New park development (2017). Parks Development Manual - 2nd Edition 2017. Retrieved at: https:// ottawa.ca/en/city-hall/planning-and-development/ new-park-development and https://ottawa.ca/en/ park-development-manual-second-edition-2017

Nochian, A., Tahir, O. M., Maulan, S., Rakhshanderoo, M. (2015). A comprehensive public open space categorization using classification system for sustainable development of public open spaces. Alam Cipta, 8 (1), 29-40.

Parks and amenity open space strategy (2013). Dover District Council.https://www.dover.gov.uk/Planning/ Planning-Policy-and-Regeneration/PDF/Parks-andAmenity-Open-Space-Strategy.pdf

Pokharel, R. P., \& Khanal, N. R. (2018). Open space: Typology and distribution in Pokhara Lekhnath metropolitan city. The Geographical Journal of Nepal, $11,25-44$.

Rakhshandehroo, M. (2014). Establishing new urban green spaces classification for Malaysian cities. Conference: IFLA 2014 Asia Pacific Congress, At Kuching, Malaysia, April 2014, 1,534 DOI: 10.13140/RG.2.1.3912.6880

Rey, G. G., Barrigon, M. J. M., Montes, G. D., \& Atanasio, P. M. (2018). Relationships among satisfaction, noise perception, and use of urban green spaces. Science of the total environment, 624, 438450. https://doi.org/10.1016/j.scitotenv.2017.12.148

Rupprecht, C. D. D., \& Furuya, K. (2017). Spatial typology in informal urban green spaces: The case of Ichikawa city, Japan. Japan Geoscience Union. Retrieved at: https://confit.atlas.jp/guide/event-img/jpguagu2017/HSC06-09/public/pdf?type =in.

Scottish nature heritage (2005). Minimum standards for open spase. Retrieved at: http://www.gov.scot/Pu blications/2005/07/18104215/42277

Southampton's Green Space Strategy Summary and Action Plan (2005). Information from Southampton City Council about Southampton's Parks and Green Spaces. Retrieved at: https://www.southampton. gov.uk/policies/green $\% \quad 20$ space $\% 20$ strategy $\% 20$ summary\%20and \%20action\%20plan_tem63363566.pdf

Stanley, B. W., Stark, B. L., Johnston, K. L., \& Smith, M. E. (2012). Urban open spaces in historical perspective: a transdisciplinary typology and analysis. Urban geography, 33 ( 8), 1089-1117. https://doi. org/10.2747/0272-3638.33.8.1089

Sytnik, T. M. (2014). Land for green areas in settlements as an object of legal relations. Journal of the Kyiv University of Law, 3, 86-93(in Ukrainian).

Tolkachenko, O. V. (2009). Some aspects of the legal status of green spaces in cities. Bulletin of the Odessa National University: Jurisprudence, 14 (1), 96-103 (in Ukrainian).

Young, R., Zanders, J., \& Fassman-Beck, E. (2014). A comprehensive typology for mainstreaming urban green infrastructure. Journal of Hydrology, 519 (27), 2571-2583. 
Yu, Z., Wang, Y., Deng, J., Shen, Z., Wang, K., Zhu, J., \& Gan, M. (2017). Dynamics of hierarchical urban green space patches and implications for management policy. Sensors, 17 (6), 1304. https://doi.org/10.3390/ s17061304

Yukhnovskyi, V., \& Zibtseva, O. (2018). Comparative analysis of classification of plantations of settlements of Ukraine and post-Soviet countries. Proceedings of the Forestry Academy of Sciences of Ukraine, 16, 9098 (in Ukrainian).

Yusof, M., Yusof, M. J., Johari, M. (2013). True colours of urban green spaces: identifying and assessing the qualities of green spaces in Kuala Lumpur, Malaysia. Retrieved at: http://hdl.handle.net/1842/8111

$\mathrm{Zi}, \mathrm{T}$. (2011). Development tendency of urban park in China. International Conference on Applied Social Science, Changsha, China, March, 19-20 (ICASS 2011), III , 223-228.

\section{Типология и классификация как методы категоризации зеленого пространства}

\section{В.Ю. Юхновский', О.В. Зибцева ${ }^{2}$}

Установлено, что основными методами категоризации открытого зеленого пространства является типология, которая касается типов открытого пространства без учета их внутренних характеристик, и классификация, которая учитывает внутренние количественные и качественные показатели пространства. Классификационный метод распределения открытого пространства базируется на трех подходах: иерархия охвата или обслуживания, функции и структуры пространства. Объем обслуживания обусловлен географической территорией, размером, уровнем использования, удаленностью. Разные страны адаптировали метод классификации, основанный на функциях классификации их национальных систем зеленых пространств.

Использование иерархической классификации (на национальном, региональном и городском уровнях) в таких странах, как Малайзия, Австралия, частично США, Канаде, делает возможным ландшафтное планирование в национальном масштабе с реализацией основного принципа озеленения - равномерности и стандартной доступности зеленого про-

Юхновский Василий Юрьевич - академик Лесной академии наук Украины, доктор сельскохозяйственных наук, профессор кафедры возобновления лесов и лесных мелиораций. Национальный университет биоресурсов и природопользования Украины, ул. генерала Родимцева, 19, г. Киев, 03041, Украина. Тел.: +38-067-720-32-16. E-mail: yukhnov@ukr.net

Зибцева Ольга Васильевна - кандидат сельскохозяйственных наук, доцент кафедры ландшафтной архитектуры и садовопаркового строительства. Национальный университет биоресурсов и природопользования Украины, ул. генерала Родимцева, 19, г. Киев, 03041, Украина. Тел.: +38-050-835-77-74. E-mail: stplut2017@gmail.com странства для всех слоев населения. Иерархическая классификация парков (например, в Оттаве) и четкие стандарты их размера, размещения, радиуса зоны обслуживания делает ее эталонным инструментом разработки новых рекреационных пространств.

Дальневосточные страны используют двухуровневую (Китай) и трехуровневую (Япония) классификации зеленого пространства с соответствующими ступенями: места общего пользования, открытые зеленые пространства, парки и ландшафтные объекты. Малайзийская классификация открытого пространства базируется на иерархии обслуживания, а североамериканская и австралийская системы открытых пространств используют функциональный, иерархический и ландшафтный подходы.

Проанализированы типологии зеленого пространства и классификации парков в постсоветских (Украина, Белорусь), европейских (Великобритания), североамериканских (США, Канада), азиатских (Япония, Китай, Сингапур, Малайзия) странах и в городах Австралии. Выявлено, что разные страны предлагают свои классификации зеленого пространства, основанные на функциональном назначении территории, физических характеристиках, размерах, объемах обслуживания населения и т.д.

В Украине, как и в классификации зеленого пространства Белоруси, используется простая и довольно удобная классификация парков по их месторасположению относительно городских границ: городские и загородные парки (как правило, лесопарки) и парки по функциональному признаку. Сейчас парки в зависимости от характера и назначения разделяют на парки культуры и отдыха, районные, спортивные, детские, дендрологические, исторические, национальные, мемориальные, этнографические паркимузеи, исторические, выставочные, зоологические, аэрофитотерапии и т.п.

Отсутствие иерархической классификации и соответствующих стандартов приводит к поглощению зеленого пространства городской застройкой. Осуществлен поиск путей совершенствования классификации зеленых насаждений, используемой в Украине. Природные территории и зеленые насаждения ограниченного пользования (школьных участков, спортивных площадок жилых массивов) являются наиболее уязвимыми территориями, которые в первую очередь попадают под застройку в украинских городах. Четко прописанная классификация озелененных территорий будет способствовать их сохранению в условиях растущей урбанизации. Рекомендуется стандартизировать украинскую классификацию зеленых насаждений, в том числе и по иерархическим признакам, что повлияет не только на систему зеленых насаждений городов, но и на ландшафтную организацию пространства за их пределами.

Ключевые слова: зеленая инфраструктура; зеленые насаждения; парк; ландшафтная организация пространства; озеленение; рекреация; городские леса. 


\section{Typology and classification as methods of categorization of green space}

\section{Yukhnovskyi' ${ }^{1}$ O. Zibtseva ${ }^{2}$}

The paper author analyses the typologies of green space and the classifications of parks of postSoviet (Ukraine, Belorussia), European (UK), North American (USA, Canada), Asian (Japan, China, Singapore, Malaysia) countries and cities of Australia. It has been found out that different countries proposed the offer classifications based on the functional purpose of the territory, the physical characteristics of the green space, the size and volume of service of the population, and so on.

It is established that the main methods of categorization of open green space are a typology that deals with types of open space without taking into account their internal characteristics, and a classification that takes into account internal quantitative and qualitative parameters of space. Classification method of the distribution of open space is based on three approaches: hierarchy of coverage or service, functions and structure of space. The amount volume of service is determined by the geographical area, size, level of use, remoteness.

Different countries have adapted a classification method based on the functions of the classification of their national systems of green spaces. Use of hierarchical classifications (at national, regional and urban levels) in countries such as Malaysia, Australia,

\footnotetext{
Vasyl Yukhnovskyi - a full Member of the Forest Academy of Sciences of Ukraine, Doctor of Agricultural Sciences, Professor of the department of forests restoration and forest meliorations. National University of Life and Environmental Sciences of Ukraine, st. General Rodimtsev, 19, Kyiv, 03041, Ukraine. Tel. + 38-067-720-32-16. E-mail: yukhnov@ukr.net

Olga Zibtseva - Candidate of Agricultural Sciences, Assistant professor of the department of landscape architecture and gardening. National University of Life and Environmental Sciences of Ukraine, st. General Rodimtsev, 19, Kyiv, 03041, Ukraine. Tel: +38-050-835-77-74. E-mail: stplut2017@gmail.com
}

partly the United States, Canada, etc. makes possible landscape planning on a national scale with the implementation of the basic principle of greening the uniformity and standard availability of green space for all segments of the population. The hierarchical classification of parks (for example, in Ottawa) and clear standards regarding their size, location, radius of service area makes it a reference tool for developing new recreational spaces and a model for imitation. Far Eastern countries use the two-level (China) and three-level (Japan) classification of green space with appropriate levels: public spaces, open green spaces, parks and landscapes. The Malaysian classification of open space is based on a service hierarchy, while the North American and Australian open spaces systems use functional, hierarchical, and landscape approaches.

Instead, in Ukraine, as in the classification of greened areas of Belarus, a simple and fairly convenient classification of parks in a location relative to city boundaries is used: urban and suburban (as a rule, forest parks) and on a functional basis. At present, parks, depending on their nature and purpose, are divided into cultural and recreational parks, regional, sports, children's, dendrological, historical, national, memorial, ethnographic parks-museums, historical, exhibition, zoological, aerophototherapy etc. The lack of a hierarchical classification and corresponding standards leads to the absorption of green spaces by urban buildings. It's searched ways to improve the classification of green areas used in Ukraine. Natural areas and green plantations of limited use (of schools, sports plots at the residential areas) are the most vulnerable territories that are primarily to be built in Ukrainian cities. A well-defined classification of green areas will contribute to their conservation in a context of growing urbanization. It is recommended to standardize the Ukrainian classification of green plantations, including hierarchical features, which will affect not only the city system of green plantations, but also the landscape organization of the space around the cities.

Key words: green infrastructure; green plantations; park; landscape organization of space; landscaping; recreation; urban forests. 